<原 著 $>$

特発性門脈圧え進症：門脈血行動態よりみた脾原説

\begin{tabular}{|c|c|c|c|c|c|}
\hline 大西久化彦 & 斉藤 & 正之 & 田中 & 秀雄 & 信義 \\
\hline 左藤 慎一 & 寺林 & 秀际 & 斉藤 & 正明 & 杉田周次郎 \\
\hline 雄一 & 中田 & 恒 & 早坂 & 章 & 波多野 \\
\hline 山 隆雅 & 飯田 & 真司 & 野村 & 文夫 & 奥田 \\
\hline
\end{tabular}

\begin{abstract}
要 旨：17人の特発性門脈圧元進症を肝容積当りの門脈血流量により $\mathrm{A}$ 群 $(\mathrm{n}=8), \mathrm{B}$ 群 $(\mathrm{n}=9)$ にわけた。A群の肝容積当りの門脈血流量はいずれも21人の正常人のそれをこ光，A群の平均 は正常人の平均 $50 \mathrm{~m} l / \mathrm{min} / 100 \mathrm{~cm}^{3}$ 肝容積の約 3 倍を示した. B 群の肝容積当りの門脈血流量は いずれも正常範囲内であった。 A 群の脾血流量の平均は正常人の平均 $120 \mathrm{~m} l / \mathrm{min}$ の約 4.2 倍, B 群のそれは約2.6倍と著明に增加していた。門脈血管抵抗はA 群では正常値を示していたが $\mathrm{B}$ 群 では著明に上昇し， $\mathrm{A}$ 群の約 3 倍を示した。聞脈圧は $\mathrm{A}$ 群 $17.7 \pm 5.5 \mathrm{mgHg}, \mathrm{B}$ 群 $23.4 \pm 3.9$ $\mathrm{mmHg}$ と上昇していた。肝容積当りの門脈血流量と門脈血管抵抗は有意の負の一次相関を示し た. 以上より特発性門脈圧元進症の門脈圧六進は脾血流量の增加に続く門脈血流量の增加によ るものと, 門脈血管抵抗の上昇によるすのがあり, 前者, 後者がそれぞれ初期, 進行病変を表 わしている可能性が強いが，両者が別の病因による可能性もある。
\end{abstract}

索引用語：特発性門脈圧元進症 肝容積当り門脈血流量 脾血流量 門脈血管抵抗 門脈圧

緒言

特発性門脈王六進症は, 脾腫, 脾機能六進, 門脈圧 元進を示すが, 肝硬变へ移行しない独立した肝疾患で ある(1ー4. しかし，幾多の研究にもかかわらず今な抆 因は明らかでないまた特発性門脈圧六進症の門脈圧 六進の機序についても幾多の研究があり，昔は脾腫に すとずく脾血流量の増大によるとするすのがあった $か^{\mathbf{5} 5,6)}$ ，最近では門脈血管抵抗の上昇が主因であるとす る考えが強い3,4.7.8). しかしいずれも間接的な証明か， 病期を考虑しない倹討であった。 今回, 我々は特発性 門脈王六進症患者で, 肝容積あたり門脈血流量, 脾血 流量，門脈压，門脈血管抵抗等を测定し，これらを正 常人のそれぞれと対比し，また特発性門脈圧元進症患 者を 2 病期にわけ, 各病期において門脈殴穴進の上昇 に何が重要かを明らかにする事を目的とした。

対象及ひ方法

対象は特発性門脈王六進症(IPH) 7 例, 正常人21例 （男：女 $=17: 4$, 年龄 $43 \pm 13$ 歳)で, IPH の入院時の

- 千藮大学第 1 内科

<受付日60年 7 月 24 日>
肝機能, 臨床所見は Table 1の如くである. IPH の診 断は特発性門脈圧六進应調查研究班の診断の手引に よった。早朝空腹時, IPH 患者をX 線透視台にて背卧 位とし, 既報9 -11)の如く，5.0F のカテーテルを門脈本

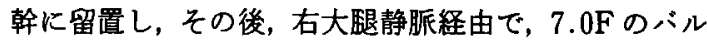
ンカテーテルを右肝静脈に留置, 門脈圧 (PVP), 閉塞 肝静脈圧 (WHVP), 自由肝静脈圧 (FHVP) を測定し た. PVP, WHVP, FHVP の 0 点は任意にX線透視台 上 $10 \mathrm{~cm}$ とした．続いてセクタ電子スキャン・バルス ドップラー複合装置を用いて門脈血流速度 (PVV), 門 脈断面積, 門脈血流量(PVF), 脾静脈血流速度(SVV), 脾静脈断面積, 脾静脈血流量 (SVF) を既報 ${ }^{12-15)}$ の如 く測定した。肝血流量 (EHBF) は Indocyanine green （ICG）を用い，肝での除去率を考感して既報の如く測 定した．肝内短絡率 (IHS) は既報》の方法に準じ，99m Tc-MAA $5 \mathrm{mCi}$ を肝門部門脈内に注入し，肝及び肺の 放射能活性を求めて測定した。肝 (LV)・脾容積 (SV) はX線 CT を用いて，肝・脾を全域にわたり， $1 \mathrm{~cm}$ ス ライスで切り，積分法にて算出した ${ }^{16)}$. 門脈血管抵抗 (Rpv)，類洞前血管抵抗 (Rpre)，類洞後血管抵抗 （Rpost）は，各々次式より求めた. 
Table 1 Clinical data on patients with IPH studied.

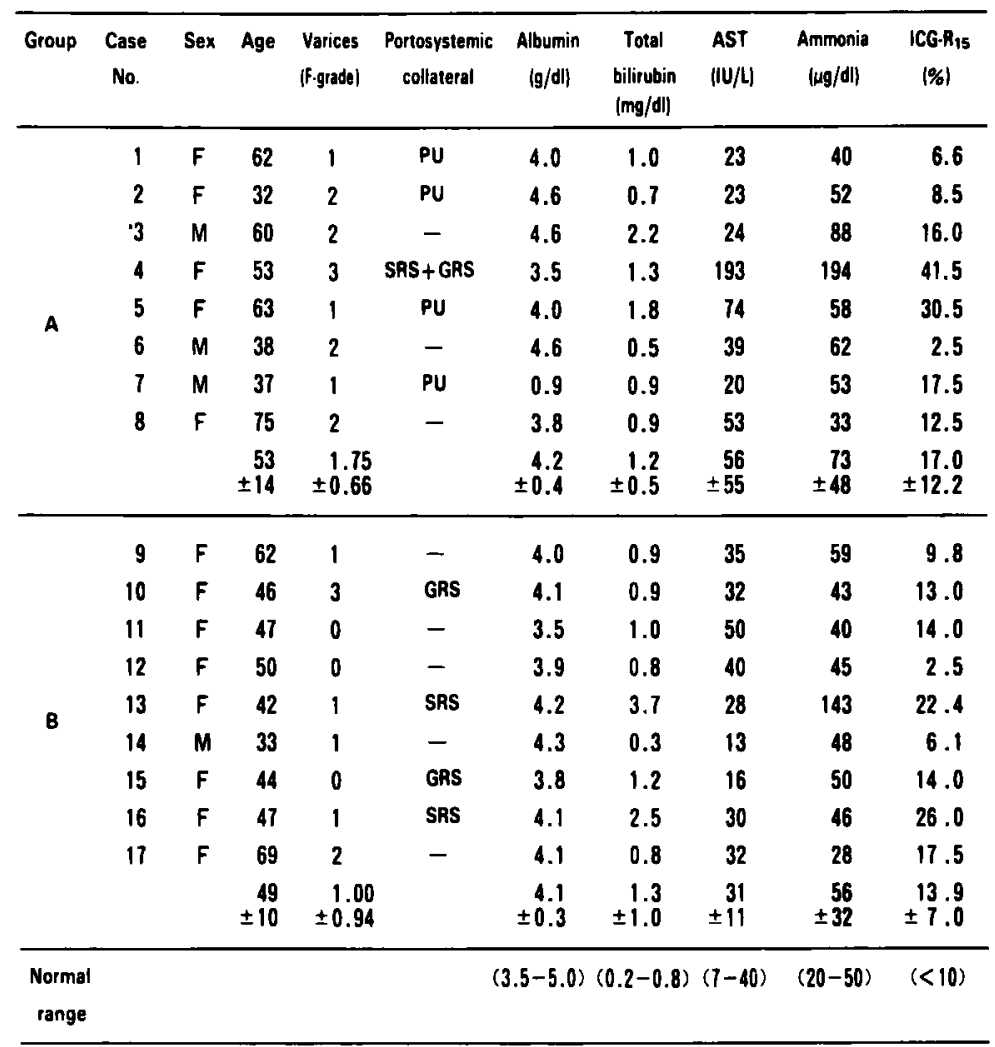

*The form ( $F$ ) of the varices was graded according to the criteria of Japanese Reseach Society for Portal Hypertension (20) and the veins described as $F_{1}=$ $1, F_{2}=2$, or $F_{3}=3$. Abbreviations : $P U$, paraumbilical vein ; $S R S$, splenorenal shunt; GRS, gastrorenal shunt.

$\mathrm{Rpv}=(\mathrm{PVP}-\mathrm{FHVP}) /\left(\mathrm{PVF} / 100 \mathrm{~cm}^{3} \mathrm{LV}\right)$

Rpre $=($ PVP - WHVP $) /\left(\right.$ PVF $\left./ 100 \mathrm{~cm}^{3} \mathrm{LV}\right)$

Rpost $=($ WHVP - FHVP $) /\left(\right.$ EHBF $\left./ 100 \mathrm{~cm}^{3} \mathrm{LV}\right)$

正常人では，早期空腹時背臥位とし，PVV，門脈断面 積, PVF, SVV, 脾静脈断面積, SVF, LV, SV を求め た.

数字は全て平均士1S.D. で表わし，有意差検定は Student's Non-paired t-testによった。相関関係は, 一次回㷌曲線にて求めた。0.05以下の P值は有意と考 えた。

成 績

今回対象とした正常群, IPHいずれる，門脈血流, 脾静脈血流は求肝性血行を示した。IPH の肝容積当り のPVFは8名が正常群のこれをこえ，9名が正常群 の範囲内であったので, 前者, 後者を A群, B群とし, 正常群との対比で以下の検討をした。䦥脈一全身短絡
路の検討ではA群の 4 名は拡張した傍脐静脈を有し， 1 名が脾腎・胃腎短絡路を有していた，B群の 2 名が 脾堅短絡路を，2名が胃腎短絡路を有していた，門脈 断面積はA 群 $1.87 \pm 0.91 \mathrm{~cm}^{2}, \mathrm{~B}$ 群 $1.29 \pm 0.29 \mathrm{~cm}^{2}$ で, 正常群の0.79 $0.24 \mathrm{~cm}^{2}$ に比し有意に増加していた。 PVV は A 群 $11.9 \pm 3.3 \mathrm{~cm} / \mathrm{sce}, B$ 群 $8.5 \pm 1.4 \mathrm{~cm} / \mathrm{sec}$ で正常群 $13.8 \pm 2.7 \mathrm{~cm} / \mathrm{sec} に$ 較へ有意に减少してい た.PVF はA 群 $1,218 \pm 394 \mathrm{~m} l / \mathrm{min}, B$ 群 $640 \pm 108 \mathrm{~m} l /$ $\min$, 正常群 $632 \pm 203 \mathrm{ml} / \mathrm{min}$ でA群はB 群, 正常群の 2 倍に増加していた. LV は A 群 $831 \pm 138 \mathrm{~cm}^{3}$ ，B 群 $984 \pm 163 \mathrm{~cm}^{3}$ で正常群 $1,328 \pm 230 \mathrm{~cm}^{3}$ に較べて有意に 减少していた，肝容積当りの PVF はA 群 $145 \pm 36 \mathrm{~m} l /$ $\mathrm{min} / 100 \mathrm{~cm}^{3} \mathrm{LV}$ で正常群 $50 \pm 19 \mathrm{ml} / \mathrm{min} / 100 \mathrm{~cm}^{3} \mathrm{LV}$ の 3 倍を示した. B群は $66 \pm 13 \mathrm{ml} / \mathrm{min} / 100 \mathrm{~cm}^{3} \mathrm{LV}$ で 正常群と有意差を示さなかった。脾静脈の断面積はA

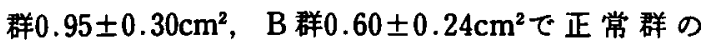


$0.25 \pm 0.10 \mathrm{~cm}^{2}$ に較べ有意に増加していた。 $\mathrm{A} \cdot \mathrm{B}$ 両群 間ではA 群のそれらは B 群に比し有意に増加してい た. SVV は正常群 $8.4 \pm 2.5 \mathrm{~cm} / \mathrm{sec}, A$ 群 $9.8 \pm 4.0 \mathrm{~cm} /$ $\mathrm{sec}, \mathrm{B}$ 群 $9.5 \pm 3.2 \mathrm{~cm} / \mathrm{sec} て ゙ ，$ 各群間で有意差なかっ た. SVF は A 群 $502 \pm 114 \mathrm{~m} l / \mathrm{min}$, B 群 $312 \pm 66 \mathrm{~m} l /$ $\min$ で正常群の $120 \pm 47 \mathrm{~m} l / \mathrm{min}$ に較べ有意に増加し ていた，A・B両群間ではB群のSVFはA群のそれに 比し有意に増加していた，SV はA群 $637 \pm 319 \mathrm{~cm}^{3}, \mathrm{~B}$

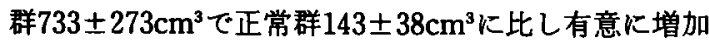
していた， A・B 両群間では有意差なかった。脾容積当 りの SVF はA群 $94 \pm 50 \mathrm{~m} l / \mathrm{min} / 100 \mathrm{~cm}^{3} \mathrm{SV}$ で正常群 の $83 \pm 16 \mathrm{ml} / \mathrm{min} / 100 \mathrm{~cm}^{3} \mathrm{SV}$ と有意差なかった。 B 群 の脾容積当りの SVF は $44 \pm 18 \mathrm{~m} l / \mathrm{min} / 100 \mathrm{~cm}^{3} \mathrm{SV}$ で，正常群に較べ有意に減少していた（Table 2).

門脈本幹へのカテーテルの抙入は16例の IPH に試 み15例に成功し，症例13では肝践の萎維が強く，門脈 枝が穿刺し得なかった，症例 8 は高齢の為，施行しな
かった。肝静脈カテーテル法は全例に施行した，PVP は B 群23.4 $\pm 3.9 \mathrm{mmHg}$ で, $\mathrm{A}$ 群の $17.7 \pm 5.5 \mathrm{mmHg}$ に較へ有意に上昇していた，それに比しWHVPはA

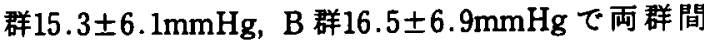
で有意差なかった，RpvはA群 7 例，A 群 8 例で測定 した。A 群の Rpv は $0.077 \pm 0.027 \mathrm{mmHg} / \mathrm{ml} / \mathrm{min} /$ $100 \mathrm{~cm}^{3} \mathrm{LV}$ (範囲0.033 0.115) で実験的に犬で報告 されている正常値 $0.075 \mathrm{mmHg} / \mathrm{ml} / \mathrm{min} / 100 \mathrm{~g}$ 肝重量

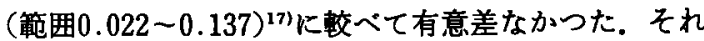
に比し，B群の Rpv は0.243 $\pm 0.061 \mathrm{mmHg} / \mathrm{ml} / \mathrm{min} /$ $100 \mathrm{~cm}^{3} \mathrm{LV}$ (範囲0.179 0.345)でいずれも正常值を 越えていて，B群の $\mathrm{Rpv}$ の平均値はA 群のそれの3.2 倍であった．Rpv と肝容積当りの PVFの関㐿は Fig. 1に示す如く，両者間には有意の負の一次相関が認めら れ, Rpv の上昇につれ, 肝容積当りの PVFが減少して いる事が明らかになった. Rpre はA群 6 例，B群 6 例 で測定した. B 群の Rpreは0.117 $\pm 0.048 \mathrm{mmHg} / \mathrm{ml}$

Table 2 Results of hemodynamic study in patients with IPH (1).

\begin{tabular}{|c|c|c|c|c|c|c|c|c|c|c|c|}
\hline Group & $\begin{array}{l}\text { Case } \\
\text { No. }\end{array}$ & $\begin{array}{c}\text { LV } \\
\left(\mathrm{cm}^{3} \mid\right.\end{array}$ & $\begin{array}{l}\text { Crost: } \\
\text { suctional } \\
\text { ares of } \\
\text { ports1 } \\
\text { voinicmen }\end{array}$ & $\begin{array}{l}\text { PVV } \\
{[\mathrm{cm} / \mathrm{ctc}]}\end{array}$ & $\begin{array}{r}\text { PV } \\
\{\mathrm{m} / \mathrm{min}\}\end{array}$ & $\begin{array}{l}\text { VF } \\
\text { (mil/minl } \\
100 \mathrm{~cm}^{3} \text { เท }\end{array}$ & $\begin{array}{l}\text { SV } \\
\left.(\mathrm{sm})^{3}\right)\end{array}$ & $\begin{array}{l}\text { Cross:- } \\
\text { sectional } \\
\text { ares of } \\
\text { splenic } \\
\text { veinicm }\end{array}$ & $\begin{array}{l}\text { SVV } \\
\{\mathrm{cm} / \mathrm{sec}\}\end{array}$ & $\begin{array}{r}\text { SV } \\
|\mathrm{m} / \mathrm{min}|\end{array}$ & $\begin{array}{l}\mid \mathrm{m} / \mathrm{min} / \\
100^{3} \mathrm{~cm} \mathrm{SV}\end{array}$ \\
\hline \multirow{9}{*}{$\mathbf{A}$} & 1 & 930 & 1.21 & 15.1 & 1095 & 118 & 359 & 0.63 & 10.6 & 401 & 112 \\
\hline & 2 & 825 & 1.54 & 12.4 & 1146 & 139 & 613 & 1.12 & 5.8 & 390 & 64 \\
\hline & 3 & 812 & 1.54 & 10.8 & 998 & 123 & 670 & 0.88 & 7.6 & 401 & 60 \\
\hline & 4 & 462 & 0.79 & 10.1 & 479 & 104 & 396 & 0.45 & 18.2 & 491 & 124 \\
\hline & 5 & 806 & 3.66 & 5.8 & 1274 & 158 & 1317 & 1.36 & 7.0 & 571 & 43 \\
\hline & 6 & 1123 & 3.08 & 10.3 & 1903 & 169 & 906 & 1.21 & 7.3 & 530 & 58 \\
\hline & 7 & 712 & 1.54 & 17.4 & 1608 & 226 & 374 & 0.99 & 12.3 & 731 & 195 \\
\hline & 8 & 980 & 1.60 & 12.9 & 1238 & 126 & 462 & - & - & - & - \\
\hline & & $\begin{array}{r}831^{\circ} \\
\pm 183\end{array}$ & $\begin{array}{r}1.87^{c .0} \\
\pm 0.91\end{array}$ & $\begin{array}{l}11.9^{1, h} \\
\pm 3.3\end{array}$ & $\begin{array}{r}1218^{i, j} \\
\pm 394\end{array}$ & $\begin{array}{c}145^{k, 1} \\
\pm 36\end{array}$ & $\begin{aligned} & 637^{\mathrm{m}} \\
\pm & 319\end{aligned}$ & $\begin{aligned} & 0.95^{0.4} \\
\pm & 0.30\end{aligned}$ & $\begin{array}{r}9.8 \\
\pm 4.0\end{array}$ & $\begin{aligned} 502^{\prime} \\
\pm 114\end{aligned}$ & $\begin{array}{c}94^{u, v} \\
\pm 50\end{array}$ \\
\hline \multirow{10}{*}{ B } & 9 & 945 & 1.13 & 8.2 & 556 & 59 & 408 & - & - & - & - \\
\hline & 10 & 1180 & 1.45 & 8.1 & 705 & 60 & 774 & 0.76 & 8.8 & 400 & 52 \\
\hline & 11 & 1265 & 1.28 & 9.9 & 760 & 60 & 1389 & 0.45 & 9.7 & 262 & 19 \\
\hline & 12 & 1154 & 1.13 & 7.5 & 509 & 44 & 488 & 0.41 & 13.9 & 342 & 70 \\
\hline & 13 & 766 & 0.92 & 9.1 & 502 & 66 & 598 & 0.45 & 12.0 & 381 & 64 \\
\hline & 14 & 922 & 1.81 & 7.3 & 793 & 86 & 728 & 1.03 & 3.6 & 222 & 30 \\
\hline & 15 & 870 & 1.17 & 7.6 & 534 & 61 & 835 & 0.34 & 11.7 & 239 & 29 \\
\hline & 16 & 833 & 1.72 & 7.0 & 722 & 87 & 836 & 0.79 & 7.2 & 341 & 41 \\
\hline & 17 & 918 & 0.99 & 11.5 & 683 & 74 & 543 & - & - & - & - \\
\hline & & $\begin{array}{r}984^{b} \\
\pm 163\end{array}$ & $\begin{aligned} & 1.29^{\text {d.॰ }} \\
& \pm 0.29\end{aligned}$ & $\begin{aligned} & 8.5^{\mathrm{g} \cdot \mathrm{h}} \\
\pm & 1.4^{-}\end{aligned}$ & $\begin{array}{r}640^{i} \\
+108\end{array}$ & $\begin{array}{r}66^{1} \\
\pm 13\end{array}$ & $\begin{array}{r}733^{n} \\
\pm 173\end{array}$ & $\begin{aligned} & 0.60^{\text {P.q }} \\
\pm & 0.24\end{aligned}$ & $\begin{array}{r}9.5 \\
+3.2\end{array}$ & $\begin{array}{l}312^{3.1} \\
\pm 66\end{array}$ & $\begin{array}{r}44^{v \cdot w} \\
\pm 18\end{array}$ \\
\hline \multirow{2}{*}{$\begin{array}{l}\text { Normal } \\
\text { values }\end{array}$} & & $1328^{0 . b}$ & $0.79^{\mathrm{c}, \mathrm{d}}$ & $13.8^{1.0}$ & $632^{i}$ & $50^{k}$ & $143^{m, n}$ & $0.25^{\circ . p}$ & 8.4 & $120^{1.2}$ & $83^{\text {U.w }}$ \\
\hline & & \pm 230 & \pm 0.24 & \pm 2.7 & \pm 203 & \pm 19 & \pm 38 & \pm 0.10 & \pm 2.5 & \pm 47 & \pm 16 \\
\hline
\end{tabular}

Superscript letters indicate significance of difference between pairs of values having the same letter. For pairs a, p<0.001; for pairs b, c, d, g, i, j, k, l, m, n, $o, p, r, s, t$, and $w, p<0.001$; for pairs $h, q$, and $v, p<0.02$; for pairs $e, f$, and $u, p=$ not significant. 
Table 3 Results of hemodynamic study in patients with IPH (2).

\begin{tabular}{|c|c|c|c|c|c|c|c|c|c|}
\hline Group & $\begin{array}{l}\text { Case } \\
\text { No. }\end{array}$ & $\begin{array}{l}\text { PVP } \\
\text { (mmHg) }\end{array}$ & $\begin{array}{l}\text { WHVP } \\
\text { (mmHg) }\end{array}$ & $\begin{array}{l}\text { FHVP } \\
\text { (mmHg| }\end{array}$ & $\begin{array}{c}\mathrm{R}_{\mathrm{pv}} \\
{[\mathrm{mmH} \mathrm{Hg} / \mathrm{m} \mathrm{m} / \mathrm{min} /} \\
100 \mathrm{~cm}^{3} \mathrm{l} \mathrm{lV} \mid\end{array}$ & $\begin{array}{c}\text { Rpre } \\
\text { (mmHHg/m/min/ } \\
100 \mathrm{~cm}^{3} \mathrm{l}(\mathrm{V})\end{array}$ & $\begin{array}{l}\text { EHBF } \\
{[\mathrm{ml} / \mathrm{min} /} \\
100 \mathrm{~cm}^{3} \mathrm{IV} \mid\end{array}$ & $\begin{array}{c}\text { Rpost } \\
{[\mathrm{mm} H \mathrm{Hg} / \mathrm{ml} /} \\
\mathrm{min} / 100^{3} \mathrm{l} \mathrm{V} \mid\end{array}$ & $\begin{array}{l}\text { IHS } \\
|\%|\end{array}$ \\
\hline \multirow{9}{*}{ A } & 1 & 11.0 & 11.5 & 7.1 & 0.033 & -0.004 & 131 & 0.027 & 2.8 \\
\hline & 2 & 17.6 & - & 7.7 & 0.071 & - & - & - & - \\
\hline & 3 & 12.6 & 8.1 & 1.5 & 0.090 & 0.037 & - & - & 0 \\
\hline & 4 & 13.6 & 13.6 & 5.9 & 0.074 & 0 & - & - & - \\
\hline & 5 & 23.1 & 9.6 & 6.2 & 0.107 & 0.085 & - & - & - \\
\hline & 6 & 27.6 & 17.6 & 8.1 & 0.115 & 0.059 & 182 & 0.025 & 6.0 \\
\hline & 7 & 18.5 & 19.8 & 6.9 & 0.051 & -0.006 & 183 & 0.054 & 17.3 \\
\hline & 8 & - & 26.9 & 6.3 & - & - & - & - & - \\
\hline & & $\begin{array}{l}17.7^{\circ} \\
\pm 5.5\end{array}$ & $\begin{array}{l}15.3^{b} \\
\pm 6.1^{\circ}\end{array}$ & $\begin{array}{r}6.0^{c} \\
\pm 2.0^{\circ}\end{array}$ & $\begin{aligned} & 0.077^{\mathrm{d}} \\
& \pm 0.027\end{aligned}$ & $\begin{aligned} & 0.029^{\circ} \\
\pm & 0.035\end{aligned}$ & $\begin{array}{l}165^{\prime} \\
\pm 24\end{array}$ & $\begin{aligned} & 0.035^{\circ} \\
\pm & 0.013\end{aligned}$ & $\begin{array}{r}6.5^{\mathrm{h}} \\
\pm \\
\pm 6.6\end{array}$ \\
\hline \multirow{10}{*}{ B } & 9 & 22.6 & 10.1 & 8.6 & 0.237 & 0.212 & 79 & 0.019 & 3.5 \\
\hline & 10 & 19.1 & 13.5 & 8.2 & 0.182 & 0.093 & 67 & 0.080 & 0 \\
\hline & 11 & 23.2 & 18.5 & 7.6 & 0.260 & 0.078 & 120 & 0.090 & - \\
\hline & 12 & 22.7 & - & 7.5 & 0.345 & - & 73 & - & 4.9 \\
\hline & 13 & - & 28.0 & 9.9 & - & - & 73 & 0.248 & - \\
\hline & 14 & 29.4 & 23.5 & 8.8 & 0.240 & 0.069 & - & - & 10.3 \\
\hline & 15 & 28.3 & - & 7.6 & 0.339 & - & - & - & - \\
\hline & 16 & 16.9 & 6.5 & 1.3 & 0.179 & 0.120 & 41 & 0.127 & - \\
\hline & 17 & 24.8 & 15.1 & 8.5 & 0.220 & 0.131 & 111 & 0.059 & - \\
\hline & & $\begin{array}{l}23.4^{\circ} \\
\pm 3.9^{\circ}\end{array}$ & $\begin{array}{c}16.5^{b} \\
\pm 6.9\end{array}$ & $\begin{array}{r}7.6^{\mathrm{c}} \\
\pm 2.2^{2}\end{array}$ & $\begin{aligned} & 0.243^{\mathrm{d}} \\
\pm & 0.061\end{aligned}$ & $\begin{aligned} & 0.117^{\circ} \\
\pm & 0.048\end{aligned}$ & $\begin{array}{r}81^{\prime} \\
+25\end{array}$ & $\begin{aligned} & 0.104^{9} \\
\pm & 0.072\end{aligned}$ & $\begin{array}{r}4.7^{n} \\
\pm 3.7\end{array}$ \\
\hline $\begin{array}{c}\text { Normal } \\
\text { range }\end{array}$ & & & 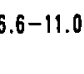 & & & & & & \\
\hline
\end{tabular}

Superscript letters indicate significance of difference between pairs of values having the same letter. For pairs $a, p<0.05$; for pairs $d, p<0.001$; for pairs $e$, and $f, p<0.01$; for pairs $b, c, g$, and $h, p=$ not significant.

$\mathrm{min} / 100 \mathrm{~cm}^{3} \mathrm{LV}$ でA 群 の0.029 $00.035 \mathrm{mmHg} / \mathrm{ml}$ $\min / 100 \mathrm{~cm}^{3} \mathrm{LV}$ に比し，有意に上昇していた. Rpost はA群の 3 例と $\mathrm{B}$ 群の 7 例で湘定した。A群の肝容積 当りの $\mathrm{EHBF} は 165 \pm 24 \mathrm{~m} l / \mathrm{min} / 100 \mathrm{~cm}^{3} \mathrm{LV}$ で B 群 の $81 \pm 25 \mathrm{ml} / \mathrm{min} / 100 \mathrm{~cm}^{3} \mathrm{LV}$ に較べ有意に増加して

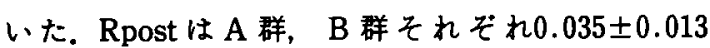
$\mathrm{mmHg} / \mathrm{ml} / \mathrm{min} / 100 \mathrm{~cm}^{3} \mathrm{LV}, 0.104 \pm 0.072 \mathrm{mmHg} /$ $\mathrm{m} l / \mathrm{min} / 100 \mathrm{~cm}^{3} \mathrm{LV}$ でB 群でA群に比し增加傾向を 示した.

\section{考 察}

今回, IPH を肝容積当りの PVFが正常群のそれを こえるすの ( $\mathrm{A}$ 群) と，こえないるの（B群）にわけ， 両群の門脈血行動態を正常群のそれと対比してみたと ころ, IPH での門脈圧六進に 2 つの因子 (PVF, Rpv) が独立して関与している事が始めて明らかになった。 即ちA群ではRpvが正常範围内におさまっているの で, A群での中等度の PVPの上年にはPVFの増加が
直接的に働いている事が明らかである. 更にPVFの 増加は主として脾腫に伴らSVFの増加にて説明さ れらる。.また正常群と異なり IPH 群では SVF 測定部 位より脾門部よりで脾静脈血流の一部が短胃静脈等を 介して，全身循環へ逃げている事が考兵られ，この事 を考慮すると，IPH で測定したSVFは実際の値より 低く測定していると考えられる.それにもかかわらず， $\mathrm{A}$ 群の脾容積当りのSVF は正常群のそれとほぼ同等 であった事は，A群における門脈圧六進には脾䐵が積 極的な役割を果していると考えられる。まA群の SVVが正常群のそれと等しかった事から考えてもA 群の脾腫はらっ血によるのではなく，増殖（過形成） によるという事が明らかである，B群においては肝容 積当りのPVFが正常範囲内におさまっていて, Rpv が著明に增加しているので，B群の高度のPVPの上 犁にはRpvの増加が直接的に働いている事が明から である. Rpvの中です，特に Rpreの上昇が B 群の 


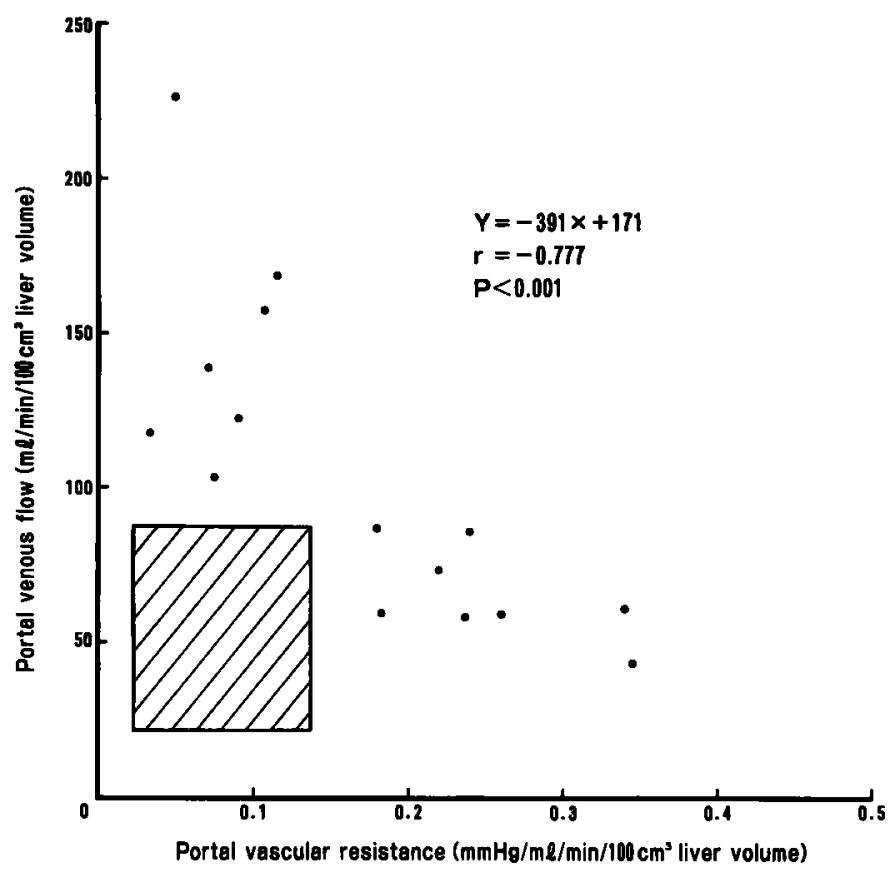

Fig. 1 Correlation between portal vascular resistance and portal venous flow per $100 \mathrm{~cm}^{3}$ liver volume $(\mathrm{r}=0.777 ; \mathrm{Y}=-391 \mathrm{X}+171 ; \mathrm{p} / 0.001)$. The crosshatched area represents normal range of portal venous flow per $100 \mathrm{~cm}^{3}$ liver volume and portal vascular resistance.

PVPの上昇に関与している事は明らかである. B群に おいてすSVFは正常群のそれに比し堌加していた か，SVFの増加はPVF の増加をひきおこさず，むし ろ食道静脈瘤を含めた肝外の門脈・全身短絡路の形成 に関与していると考兄られる。.さてA群，B群がそれ ぞれ IPH の初期，進行期病变を表わしているのか，あ るいは両群は異なる病因によるのかについて考察して みる。まず，(i) Rpv と肝容積当りのPVFが負の一次 相関を示し，Rpvの增加につれ肝容積当りのPVF が 减少する事,（ii）A群では肝缄側の門脈・全身短絡路 (傍脐静脈等)が高頻度に, B 群では肝葴より離れた脾 炡よりの門脈・全身短絡路（胃腎・脾腎短絡路）が高 頻度に形成されている事, (iii) PVPがA群に比し, B 群で有意に上昇している事, (iv) A，B両群に SVに 差がないのに, A 群の脾容積当りの SVF は正常のそ れに等しく，B群のそれが正常群の半分であることを （多少らっ血脾か）より考え，A群，B群はそれぞれ IPH の初期, 進行期病変を表わしていると考える. 以 上の成績をふまえ，IPH の成り立ちについて私見を述 ベる. ます何らかの原因で脾䯈の過形成がおこり, SVF が増加し, 門脈内へ流入する血流 (SVF) が増大
すると平行して，一部肝䒽側に肝葴を迂回する門脈・ 全身短絡路（例之ば食道静脈瘤・傍脐静脈）が発達す る.しかし門脈・全身短絡路の発達は十分でなく PVP が中等度に上昇する。この状態が持続していると門脈 系・特に門脈末梢枝の硬化性病変が発生し，また時に は一部の門脈枝に血栓が形成され，その支配領域の肝 葴の萎縮がおこり，肝表面は波打ち状を呈する，Rpv の上昇につれて，肝䁍より離れて脾䁍よりの門脈，全 身短絡路（例光ば胃腎短絡路，脾腎短絡路）が形成さ れ, 門脈血は肝䁍を迂回し, 肝容積当りのPVF が減少 するが，その減少は，十分でなく，PVPが更に上昇す る.この私見は今から17年前上田らが内科21巻， 4 号, 735 ページで特発性 (非硬変性) 門脈高圧症の成り立ち

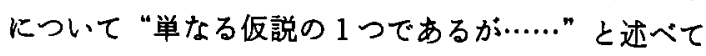
いる6)もの大筋で一致している. 私見の正しさはA 群の IPH の門脈血行動態の今後の経過観察で証明さ れよう。また私見が正しければ，IPHは主として脾臓 にPVP 上昇の一次原因があり，肝䐟や肝外門脈に PVP 上昇の一次原因がある肝硬変や肝外門脈閉塞症 とは異なった病因によると考えるのが妥当であり， IPH は脾原発の疾患と考えるのが適当之思われる。し 
かし脾腫（過形成）が腸管由来の非病原性大晹菌等の 刺激によるのか ${ }^{18,199}$ ，脾臓自身に基ずくのか，他臟器由 来のホルモン様物質に反応しておこっているのか今後 解明すべき点である。

謝辟 本研究の一部は厚生省特定疾患門脈血行巽常症調 查研究班の助成金並びに文部省科学研究費 (一般研究 B No. 59480205，一般研究 C. No. 60570311）によった.

$$
\text { 文 献 }
$$

1) Okuda $K$, Nakajima $T$, Okudaira $M$, et al: Anatomical basis of hepatic venographic alterations in idiopathic portal hypertension. Liver $1: 255-263,1981$

2) Okuda K, Nakajima T, Okudaira $M$, et al: Liver pathology of idiopathic portal hypertension. Comparison with non-cirrhotic portal fibrosis of India. Liver 2: 176-192, 1982

3) Okuda K, Kono K, Ohnishi K, et al: Clinical study of eighty-six cases of idiopathic portal hypertension and comparison with cirrhosis with splenomegaly. Gastroenterology $86: 600$ $-610,1984$

4) Okuda $K$, Nakajima $T$, Kameda $H$, et al : Idiopathic noncirrhotic portal hypertension : A national study. In : Hepatology : A Festschrift for Hans Popper, Edited by $\mathrm{H}$ Brunner, $\mathrm{H}$ Thaler. Raven Press, New York, 1985, p95-108

5) Ueda $H$, Kitani $K$, Kameda $H$, et al: Splenic blood flow in idiopathic portal hypertension in Japan measured by ${ }^{85} \mathrm{Kr}$ clearance method. Acta Hepatospleno 18: 28-40, 1971

6) 上田英雄，木谷健一，薢田治男，他：特発性(非硬 変性) 門脈高圷症一肝脾の血行力学 (II) 一内科 $21: 733-737,1968$

7) Futagawa $S$, Fukazawa M, Hirosawa $M$, et al : Portographic liver changes in idiopathic noncirrhotic portal hypertension. AJR 134 : 917-923, 1980

8) Futagawa S, Fukazawa M, Musha $H$, et al : Hepatic venography in noncirrhotic idiopathic portal hypertension. Radiology 141 : 303-309, 1981

9) Okuda K, Suzuki K, Musha H, et al: Percutaneous transhepatic chatheterization of the portal vein for the study of portal hemodynamics and shunts. A preliminary report. Gastroenterology
$73: 279-284,1977$

10) Ohnishi $K$, Nakayama $T$, Saito $M$, et al: Effects of propranolol on portal hemodynamics in patients with chronic liver disease. Am J Gastroenterol 80 : 132-135, 1985

11) Ohnishi $K$, Nakayama $T$, Saito $M$, et al: Effects of cimetidine and ranitidine on splanchnic hemodynamics in patients with chronic liver disease. Am J Gastroenterol 80 : 290-293, 1985

12) Ohnishi $K$, Saito $M$, Nakayama $T$, et al: Pulsed doppler flow as a criterion of portal venous velocity: Comparison with cineangiographic measurements. Radiology 154: 495 $-498,1985$

13) Ohnishi $K$, Saito $M$, Nakayama $T$, et al: Ultrasonic measurements of portal venous flow and its velocity in normal subjects and patients with chronic liver disease: Effect of posture change and exercise on portal hemodynamics. Radiology 155 : 757-761, 1985

14）斉藤正之, 寺林㛢隆, 中山隆雅, 他：バルドッブ ラ一複合装置に上る門脈・脾血流速度. 血流量測定 の臨床的意義. 肝藏 $25: 1281-1287,1984$

15) Ohnishi $K$, Saito $M$, Sato $S$, et al : Direction of splenic venous flow assessed by pulsed doppler flowmetry in patients with a large splenorenal shunt: Relation to spontaneous hepatic encephalopathy. Gastroenterology 89: 180-185, 1985

16) Henderson JM, Heymsfield SB, Horowitz J, et al: Measurement of liver and spleen volume by computed tomography. Radiology $141: 525$ $-527,1981$

17) Richardson PDI, Withrington PG : Liver blood flow. I. Intrinsic and nervous control of liver blood flow. Gastroenterology 81 : 159-173, 1981

18) Kono $K$, Ohnishi $K$, Okuda $K$ : Experimental portal fibrosis induced by intraportal injection of bacteria. In : Idiopathic portal hypertension, Edited by K Okuda, M Omata. Univ Tokyo Press, Tokyo, 1983, p277-289

19）杉田周次郎, 大西久彦, 斉藤正明, 他：犬門脈内 細菌注入に上る実験的門脈線䊒症の作製. 䀒䁍 $26: 1714-1718,1985$

20）日本門脈圧元進症研究会：食道静脈痹内視鏡所見 記載基準。肝䑏 $21 ： 779-783 ， 1980$ 


\title{
Portal hemodynamics in idiopathic portal hypertension (Banti's syndrome)
}

\author{
Kunihiko OHNISHI, Masayuki SAITO and Kunio OKUDA*
}

To address the long unsettled issue of whether increased splenic venous flow is the major cause of portal hypertension in Banti's syndrome, 17 cases of idiopathic portal hypertension were studied by portal and hepatic vein catheterization in comparison with 21 normal controls. Portal venous flow, splenic venous flow and portal vascular resistance were measured. It was concluded that in one group of patients with idiopathic portal hypertension, portal hypertension is mainly due to increased portal venous flow, partly a result of increased splenic venous flow; in another group, increased portal vascular resistance plays an important role. Whether these two groups represent early and advanced stages of idiopathic portal hypertension, or different etiologies remains to be elucidated.

* 1st Department of Medicine, Chiba University School of Medicine (Chiba) 